\title{
CHARACTERISTICS OF AUTOPSY MATERIAL IN CASES OF CHRONIC DIFFUSE PATHOLOGY OF THE LIVER PARENCHYMA DIAGNOSED DURING PATIENT'S LIFETIME USING THE ULTRASOUND METHOD
}

D0I: 10.36740/WLek202009218

\author{
Yuliia Ya. Fedulenkova, Mykhailo S. Myroshnychenko, Olha M. Astapieva, Aleksandr A. Fatieiev, \\ Kristina Od. Akritova, Dmytro V. Molodan \\ KHARKIV NATIONAL MEDICAL UNIVERSITY, KHARKIV, UKRAINE
}

\begin{abstract}
The aim: Of the study is to analyze autopsy cases where chronic diffuse pathology of the liver parenchyma was diagnosed during patient's lifetime using the ultrasound method. Material and methods: In this study archival material (autopsy protocols and microspecimens of these cases) of the pathological anatomy department of the Communal Nonprofit Enterprise «Regional Clinical Hospital» (Kharkiv) was used for the period from 2012 to 2018. The cases diagnosed with a chronic diffuse pathology of the liver parenchyma according to ultrasound data were selected among all cases. Microspecimens stained with hematoxylin and eosin, picrofuxin according to van Gieson were examined using an Olympus BX-41 microscope (Japan).

The obtained digital indicators were statistically processed using the programs Statistica 6.0, Microsoft Excel 2003. To compare the parameters, parametric and nonparametric methods were used (Student's t-test, $X 2$ criterion, Mann-Whitney U-test). Differences were considered significant at $\mathrm{p}<0.05$.

Results: According to the analysis of archival material for the period from 2012 to 2018, there was no change in the relative number of cases with fatty hepatosis, fibrosis or cirrhosis of the liver, chronic hepatitis, malignant tumors of the liver, metastatic liver damage and liver infiltration by leukemic cells, liver abscesses. Among all cases with revealed liver pathology, both separately by year and as a whole for the entire studied period, a predominance of the relative number of cases with fatty hepatosis, fibrosis or cirrhosis of the liver was noted.

Conclusions: The term «chronic diffuse pathology of the liver parenchyma», which is widely used in ultrasound diagnostics, is morphologically a collective term that combines pathological conditions such as fatty hepatosis, fibrosis or cirrhosis of the liver, chronic hepatitis, malignant tumors of the liver, metastatic liver damage and liver infiltration by leukemic cells, liver abscesses.

The ultrasound term «chronic diffuse pathology of the liver parenchyma» needs to be improved as well as additional diagnostic criteria should be developed in order to correctly use it in practice and avoid diagnostic errors.
\end{abstract}

KEY WORDS: chronic diffuse pathology of the liver parenchyma, ultrasound method, morphological method

Wiad Lek. 2020;73(9 p. II):1995-1999

\section{INTRODUCTION}

Liver diseases are a global problem in modern healthcare system. There is a tendency toward a decrease in hepatological morbidity and mortality in a number of countries in southern and western Europe (France, Germany, Italy, Spain, etc.), while in some states of Eastern Europe these indicators are increasing (Bulgaria, Romania, the Baltic countries, etc.), and in some other countries it remains stable (the Netherlands, Poland, Scandinavian countries, etc.) $[1,2]$.

According to the World Health Organization there are more than 2 billion people with liver diseases in the world [3]. Ukraine has seen a significant increase in liver pathology over the past 10 years: the prevalence of chronic hepatitis has increased 2.2 times, liver cirrhosis - by $60 \%$. The increase in the incidence of chronic liver diseases is called the «second epidemic of our century» after the «epidemic» of cardiovascular diseases [4].

Liver is characterized by a strategic location and multidimensional functions that is why it is prone to many diseases. There are over 100 known forms of liver disease caused by a variety of factors [5]. In the etiological structure of liver diseases, in addition to metabolic, autoimmune, drug-induced, toxic and genetic factors, addictions and 
dependencies of modern humans - alcohol abuse, psychostimulants, eating disorders (overeating), «obesity epidemic», and the use of genetically modified organisms are becoming increasingly important against the background of an increase in prevailing hepatotropic viruses and mixed viral infections [4].

An important feature of liver diseases is their asymptomatic course in the early stages and random diagnosis during examination for other diseases (organs of the gastrointestinal tract, cardiovascular system, endocrine glands, etc.), a tendency to progression with the gradual development of liver fibrosis and cirrhosis as well as hepatocellular cancer [3].

The role of practical healthcare doctors' knowledge of the diagnostic methods for these diseases and their correct interpretation significantly increases in connection with the high levels of liver diseases prevalence. A significant role among these methods is given to ultrasound examination of the liver [6]. Here, morphological diagnostics plays a special role, i.e. biopsy or autopsy study, among diagnostic methods for studying the liver. Biopsy, according to many scientists, is the "gold standard» for the diagnosis of liver diseases. It allows us to assess the morphological and functional state of this organ, to identify pathognomonic morphological signs for a particular disease, facilitating a correct diagnosis and determining further treatment tactics for the patient $[7,8]$.

\section{THE AIM}

The aim of the study is to analyze autopsy cases where chronic diffuse pathology of the liver parenchyma was diagnosed during patient's lifetime using the ultrasound method.

\section{MATERIAL AND METHODS}

In this study archival material (autopsy protocols and microspecimens of these cases) of the pathological anatomy department of the Communal Nonprofit Enterprise «Regional Clinical Hospital» (Kharkiv) was used for the period from 2012 to 2018. The cases diagnosed with a chronic diffuse pathology of the liver parenchyma according to ultrasound data were selected among all cases. Microspecimens stained with hematoxylin and eosin, picrofuxin according to van Gieson were examined using an Olympus BX-41 microscope (Japan).

The obtained digital indicators were statistically processed using the programs Statistica 6.0, Microsoft Excel 2003. To compare the parameters, parametric and nonparametric methods were used (Student's t-test, $\chi^{2}$ criterion, Mann-Whitney U-test). Differences were considered significant at $\mathrm{p}<0.05$.

\section{RESULTS AND DISCUSSION}

Ultrasound examination of liver today is the most common radiological method for diagnosing the hepatobiliary system [9].
Feasibility of using ultrasound examination to diagnose chronic diffuse pathology of the liver parenchyma is determined by the following factors. The method is purely non-invasive and, when routinely performed, is not accompanied by disruption of tissue integrity, introduction of probes or contrast agents [10]. An important feature of the method is that it is safe because it is not associated with radiation exposure of the patient and uses a sufficiently low level of radiated power of ultrasound. This method has almost no contraindications; it is simple and not burdensome for the patient [11].

From the point of view of public health services organization thanks to existence of special modifications of devices (not only powerful for in-patient use, but also small-sized mobile for express diagnostics) the ultrasonic method is suitable for use at any stage and examination form of the patient (in polyclinic and hospital, field teams and specially equipped diagnostic centers, etc.) [12]. This method is characterized by a relatively low cost of equipment with an adequate cost-performance ratio in the economic aspect [11].

A relevant feature of the ultrasound method is that it gives the opportunity to simultaneously obtain information about the condition of related organs and tissues, which is especially important for patients with gastrointestinal profile because chronic diffuse pathology of the liver parenchyma is usually accompanied by comorbid pathology [13].

Among all cases of autopsies performed on the basis of the pathological anatomy department of the Communal Nonprofit Enterprise «Regional Clinical Hospital» (Kharkiv), chronic diffuse pathology of the liver parenchyma according to ultrasound examination making during patient's lifetime was found in 61 cases in 2012, accounting for $20.3 \%$ of the total autopsies, in 2013 - in 57 cases (15.1\%), in 2014 - in 77 cases (21.7\%), in 2015 - in 64 cases $(18.8 \%)$, in 2016 - in 76 cases $(21.2 \%)$, in 2017 - in 87 cases $(24.2 \%)$, in 2018 - in 81 cases $(21.1 \%)$. During the period from 2012 to 2018 the relative number of the above cases did not change significantly ( $p>0.05)$.

During the analysis of autopsy protocols and microscopic examination of autopsy material it was made a conclusion and morphological diagnosis in each case (table 1). Analysis of the data in table 1 shows that the used ultrasound term "chronic diffuse pathology of the liver parenchyma» is morphologically manifested as a variety of general pathological processes in the liver, characterized for various diseases, and the liver picture corresponding to age. Thus, the ultrasound term «chronic diffuse pathology of the liver parenchyma», given the few cases where the morphological picture of the liver was normal, requires improvement and development of additional diagnostic criteria in order to properly use it in practice and avoid diagnostic errors.

The ultrasound term «chronic diffuse pathology of the liver parenchyma», as noted in table 1, was morphologically manifested by fatty hepatosis with the presence of chronic venous congestion in some cases; widespread fibrosis and formation of regenerate nodules, replacing the liver parenchyma, typical for cirrhosis; liver tumors, metastatic 
Table I. Morphological analysis of chronic diffuse pathology of the liver parenchyma diagnosed by ultrasound method

\begin{tabular}{|c|c|c|c|c|c|c|c|c|}
\hline \multirow{3}{*}{ Morphological diagnosis } & \multirow{2}{*}{$\begin{array}{l}\text { Total number } \\
\text { of cases for the } \\
\text { whole period }\end{array}$} & \multicolumn{7}{|c|}{ Year } \\
\hline & & 2012 & 2013 & 2014 & 2015 & 2016 & 2017 & 2018 \\
\hline & \multicolumn{8}{|c|}{ Absolute amount /\% } \\
\hline $\begin{array}{l}\text { Fatty hepatosis or fatty } \\
\text { hepatosis with chronic } \\
\text { venous congestion }\end{array}$ & $\begin{array}{l}288 / \\
57.3\end{array}$ & $\begin{array}{l}33 / \\
54.1\end{array}$ & $\begin{array}{l}29 / \\
50.9\end{array}$ & $\begin{array}{l}42 / \\
54.5\end{array}$ & $\begin{array}{l}39 / \\
60.9\end{array}$ & $\begin{array}{l}35 / \\
46.1\end{array}$ & $\begin{array}{l}59 / \\
67.8\end{array}$ & $\begin{array}{l}51 / \\
63.0\end{array}$ \\
\hline $\begin{array}{l}\text { Fibrosis or cirrhosis of the } \\
\text { liver }\end{array}$ & $\begin{array}{c}97 / \\
19.3 \\
\end{array}$ & $\begin{array}{c}15 / \\
24.6\end{array}$ & $\begin{array}{l}13 / \\
22.8\end{array}$ & $\begin{array}{c}16 / \\
20.8\end{array}$ & $\begin{array}{c}10 / \\
15.6\end{array}$ & $\begin{array}{l}20 / \\
26.3\end{array}$ & $\begin{array}{c}11 / \\
12.6\end{array}$ & $\begin{array}{c}12 / \\
14.8\end{array}$ \\
\hline Chronic hepatitis & $\begin{array}{c}51 / \\
10.1\end{array}$ & $\begin{array}{l}6 / \\
9.8\end{array}$ & $\begin{array}{c}6 / \\
10.5\end{array}$ & $\begin{array}{l}6 / \\
7.8\end{array}$ & $\begin{array}{c}7 / \\
10.9\end{array}$ & $\begin{array}{c}10 / \\
13.2\end{array}$ & $\begin{array}{c}9 / \\
10.3\end{array}$ & $\begin{array}{l}7 / \\
8.6\end{array}$ \\
\hline $\begin{array}{l}\text { Malignant tumor of the } \\
\text { liver, metastatic lesion of } \\
\text { the liver, infiltration of the } \\
\text { liver by leukemia cells }\end{array}$ & $\begin{array}{l}43 / \\
8.5\end{array}$ & $\begin{array}{l}5 / \\
8.2\end{array}$ & $\begin{array}{c}7 / \\
12.2\end{array}$ & $\begin{array}{c}8 / \\
10.4\end{array}$ & $\begin{array}{l}6 / \\
9.5\end{array}$ & $\begin{array}{l}7 / \\
9.2\end{array}$ & $\begin{array}{l}4 / \\
4.6\end{array}$ & $\begin{array}{l}6 / \\
7.4\end{array}$ \\
\hline Liver abscesses & $\begin{array}{l}3 / \\
0.6\end{array}$ & - & - & $\begin{array}{l}2 / \\
2.6\end{array}$ & - & - & $\begin{array}{c}1 / \\
1.2\end{array}$ & - \\
\hline $\begin{array}{l}\text { Morphological picture of } \\
\text { the liver corresponds to } \\
\text { the age norm }\end{array}$ & $\begin{array}{l}21 / \\
4.2\end{array}$ & $\begin{array}{c}2 / \\
3.3\end{array}$ & $\begin{array}{l}2 / \\
3.6\end{array}$ & $\begin{array}{c}3 / \\
3.9\end{array}$ & $\begin{array}{l}2 / \\
3.1\end{array}$ & $\begin{array}{c}4 / \\
5.2\end{array}$ & $\begin{array}{c}3 / \\
3.5\end{array}$ & $\begin{array}{l}5 / \\
6.2\end{array}$ \\
\hline
\end{tabular}

damage of the liver or liver infiltration by leukemia cells; chronic hepatitis; abscesses of the liver. The revealed liver pathology in the pathoanatomical diagnosis was the main disease or concomitant pathology. For the period from 2012 to 2018 , when analyzing the dynamics of changes in the indicators of the relative number of cases with various liver pathologies, there were no $(\mathrm{p}>0.05)$ significant changes found.

In our study it has been found that among all chronic diffuse pathology of the liver parenchyma, both separately for years and for the whole studied period, a significant $(p<0.05)$ number of cases occurred in fatty hepatosis, fibrosis or cirrhosis, which was also noted in the works of domestic and foreign scientists $[2,3]$.

Fatty hepatosis or fatty hepatosis with chronic venous congestion was found more often $(\mathrm{p}<0.05)$ in men $(176$ cases, $61.1 \%$ ) compared with women (112 cases, $38.9 \%$ ). The average age of those who died with the above liver pathology was $64.1 \pm 1.5$ years, while the average age of men $(60.8 \pm 2.1$ years $)$ was significantly $(\mathrm{p}<0.05)$ lower than the average age of women (66.8 \pm 1.9 years).

In most cases it was possible to identify the cause of fatty hepatosis development when analyzing anamnestic data. So, in 179 cases $(62.2 \%)$ the cause of fatty hepatosis development was hypoxia caused by chronic pathology of the cardiovascular and respiratory systems. Endocrine and metabolic disorders (diabetes, obesity, etc.) caused the development of fatty hepatosis in 51 cases (17.7\%). In 46 cases $(16.0 \%)$ the cause of fatty hepatosis development was toxic effects due to alcohol abuse, chemotherapy in patients with malignant tumors of various localizations. It was not possible to identify its genesis in 12 cases (4.1\%).

Macroscopically the liver in fatty hepatosis was characterized by a smooth surface. The liver capsule was thin, transparent, smooth and shiny. In 263 cases (91.3\%) the liver had a dense texture and in 25 cases (8.7\%) it was flabby. In 199 cases $(69.1 \%)$ the liver on the cross section looked like nutmeg due to the presence of red, dark red, yellow and brown-yellow areas, and in 89 cases (30.9\%) it was yellow or gray-yellow.

«The nutmeg liver» was microscopically characterized by a sharp dilation and hyperemia of the central veins and adjacent inter-beam capillaries, presence of diapedetic hemorrhages and deposition of the hemosiderin pigment. On the periphery of the hepatic lobules small-droplet and large-droplet fatty degeneration of hepatocytes was determined, as a result of which the latter lost their inherent shape and beam-like arrangement, acquired a rounded shape. In 15 cases $(5.2 \%)$ there was a discompletion of hepatocytes with the presence of vacuole dystrophy, polymorphic cell infiltration of varying severity and necrosis of individual cell groups. Inflammatory changes were accompanied by a fibrosing reaction expressed to varying degrees. Hereby, portal, periportal, perivenular and perisinusoidal fibrosis was noted in some places with the formation of fibrotic septa.

In 89 cases $(30.9 \%)$ where macroscopically the liver on the cross section was yellow or gray-yellow in color scanning microscopy revealed pulverized, small-droplet, medium-droplet and in some fields of view large-droplet obesity of hepatocytes. Fatty infiltration encompassed single hepatocytes, groups of hepatocytes or the entire liver parenchyma. Fusion of fat-filled hepatocytes with the formation of fatty cysts was noted in some fields of view. It should be noted that hepatocytes with signs of fatty degeneration in part of the visual fields were localized mainly around the portal tracts, central veins and in part of the visual fields did not have any connection with the anatomical structures of the liver.

Fibrosis or cirrhosis was noted significantly $(\mathrm{p}<0.05)$ more often in men (72 cases, $74.2 \%$ ) compared with wom- 
en ( 25 cases, $25.8 \%)$. The average age of the deceased with the above pathology was $56.5 \pm 1.9$ years. The average age of men $(51.8 \pm 1.5$ years $)$ was significantly $(\mathrm{p}<0.05)$ lower than the average age of women (62.2 \pm 2.2 years).

Analyzing the clinical and anamnestic data, it has been found that the cause of liver fibrosis or cirrhosis development in 49 cases (50.5\%) was the toxic effect of alcohol, in 21 cases $(21.6 \%)$ - a chronic pathology of the cardiovascular system, which resulted in the formation of congestive or nutmeg cirrhosis of the liver, in 10 cases $(10.3 \%)$ - a viral hepatitis in anamnesis. In 9 cases $(9.4 \%)$ fibrosis or cirrhosis of the liver developed as a result of immune disorders, i.e. had an autoimmune genesis. Genesis of the above liver pathology development could not be established in 8 cases $(8.2 \%)$.

Macroscopically the liver in fibrosis or cirrhosis was reduced in size, of dense texture, diffusely deformed by numerous nodules (size from 0.3 to $0.5 \mathrm{~cm}$ ). It was revealed on the cross section the separation of liver tissue into rounded nodules bounded by fibrous bands and rings. The color of the nodules ranged from pale brown, greenish yellow to dark red.

Massive fibrous septa, dissecting the organ parenchyma, or the formation of portal cirrhosis with powerful connective tissue septa between the false hepatic lobules were observed during the microscopical examination. Portal tracts were sharply expanded with sclerotic stroma and vessels. Moderate, sometimes abundant lymphohistiocytic infiltration was noted in septum and portal tracts. Hepatocytes of false lobules were noticed in some areas with focal or diffuse small-droplet, large-droplet fatty degeneration. Hydropic degeneration of hepatocytes was determined in some fields of view, while in others - necrotic changes of liver cells. There was an increase in the number of small ductal elements, indicating proliferative processes in the bile ducts. Monolobular cirrhosis was predominant among all types of cirrhosis of the liver when the regenerative nodes were built on the basis of one fragmented lobule over the multilobular one, also when the fragments of several lobules were included in the composition of the regenerative nodes. Monomultilobular cirrhosis was not detected.

A significant $(\mathrm{p}<0.05)$ prevalence of liver fibrosis and cirrhosis, liver hepatosis in men compared with women was noted in Ukraine, according to the State Statistics Service of Ukraine, when analyzing the gender characteristics of liver pathology [14].

Chronic hepatitis was significantly $(\mathrm{p}<0.05)$ more often found in men (39 cases, $76.5 \%$ ) compared with women (12 cases, $23.5 \%$ ). The average age of those who died with this pathology was $43.3 \pm 1.5$ years. The average age was significantly $(\mathrm{p}<0.05)$ lower in men $(41.5 \pm 1.6$ years $)$ than in women ( $45.0 \pm 1.1$ years).

The results of the clinical and anamnestic analysis revealed the cause of the chronic hepatitis development. Hence, in 36 cases (70.6\%) infectious genesis of chronic hepatitis was found, in 12 cases $(23.5 \%)$ chronic hepatitis occurred as a result of toxic effects (alcohol intoxication), in 3 cases (5.9\%) metabolic disorders were the cause.
Macroscopically, the liver was of normal size, the capsule was diffusely thickened, whitish or whitish-gray in color. Liver tissue was dense, in some cases flabby. On the cross section the liver was greyish-brown or brown-yellow. Microscopically chronic persistent hepatitis was revealed in 34 cases $(66.7 \%)$, in 12 cases $(23.5 \%)$ - chronic active hepatitis, in 5 cases $(9.8 \%)$ - chronic cholestatic hepatitis.

Malignant liver tumors, metastatic liver lesion or liver infiltration by leukemia cells were significantly more common in men (31 cases, $72.1 \%$ ) compared with women (12 cases, $27.9 \%$ ). The average age of the deceased with the above pathology was $46.4 \pm 1.5$ years. The average age of men ( $46.5 \pm 1.6$ years) did not significantly differ $(\mathrm{p}>0.05)$ from the average age of women ( $46.3 \pm 1.7$ years).

Macroscopically in cases of leukemic cell infiltration, the liver was enlarged and dense, characterized by a smooth surface, a thin and transparent capsule, greyish-brown, brown or grayish-yellow color on the cross section. In cases of malignant neoplasm or metastatic tumor lesion the surface of the liver was finely tuberous in some places, coarsely tuberous in other places, the lower edge was rounded, the tissue was flabby, dark red, sometimes blackish, sometimes grayish-yellow color with alternating dense nodular formations.

Microscopic examination of the liver in 22 cases (51.2\%) showed marked diffuse proliferation of leukemic cells of the myeloid series along sinusoids and in portal tracts; diffuse fatty degeneration of hepatocytes; hyperemia of portal vessels with plasmostasis, desquamation of the endothelium and paravasal hemorrhage. In 16 cases $(37.2 \%)$ it was found a metastatic liver damage because of the development cancer of various localization (bronchus, stomach, colon, pancreas, mammary glands) and skin melanoma. Hepatocellular liver cancer was diagnosed in 3 cases (6.9\%) and cholangiocellular cancer - in 2 cases ( $4.7 \%$ ).

Liver abscesses were found in 3 men, whose average age was $42.6 \pm 1.5$ years. Clinical and anamnestic analysis, the results of macroscopic examination made it possible to interpret these abscesses as cholangiogenic. Macroscopically the size of the liver, the consistency and the color on the cross section were not changed. A few cavity formations of a round-oval shape with a diameter of 0.5 to $1.5 \mathrm{~cm}$ were found in the area of the gallbladder bed in the liver, containing a mucous mass of yellowish-greenish color in the lumen. Survey microscopy revealed acute liver abscesses.

\section{CONCLUSIONS}

1. The term «chronic diffuse pathology of the liver parenchyma», which is widely used in ultrasound diagnostics, is morphologically a collective term that combines pathological conditions such as fatty hepatosis, fibrosis or cirrhosis of the liver, chronic hepatitis, malignant tumors of the liver, metastatic liver damage and liver infiltration by leukemic cells, liver abscesses.

2. According to the analysis of archival material for the period from 2012 to 2018, there was no change in the relative number of cases with fatty hepatosis, fibrosis or cirrhosis of the liver, chronic hepatitis, malignant tumors 
of the liver, metastatic liver damage and liver infiltration by leukemic cells, liver abscesses. Among all cases with revealed liver pathology, both separately by year and as a whole for the entire studied period, a predominance of the relative number of cases with fatty hepatosis, fibrosis or cirrhosis of the liver was noted.

3. The ultrasound term «chronic diffuse pathology of the liver parenchyma», taking into account the few cases identified during the analysis where the morphological picture of the liver corresponded to the age norm, needs to be improved, as well as additional diagnostic criteria should be developed in order to correctly use it in practice and avoid diagnostic errors.

4. Hepatosis, fibrosis or cirrhosis of the liver, chronic hepatitis, malignant tumors of the liver, metastatic damage of the liver, infiltration of the liver by leukemia cells, liver abscesses develop more often in men. When analyzing the age-related features of the revealed liver pathology, it has been noted that at an earlier age patients develop liver abscesses (average age $-42.6 \pm 1.5$ years), chronic hepatitis (average age $-43.3 \pm 1.5$ years), malignant tumors of the liver, metastatic liver damage, liver infiltration by leukemia cells (average age $-46.4 \pm 1.5$ years), and at a later age - fibrosis or cirrhosis (average age $-56.5 \pm 1.9$ years), hepatosis of the liver (average age - 64.1 \pm 1.5 years). Chronic hepatosis, fibrosis or cirrhosis of the liver, chronic hepatitis in men develops at an earlier age than in women.

\section{REFERENCES}

1. Tsukanov V.V., Vasyutin A.V., Tonkikh Yu.L. et al. Bremja zabolevanij pecheni v sovremennom mire. Nekotorye pokazateli kachestva vedenija bol'nyh s cirrozom pecheni v Sibirskom federal'nom okruge. The burden of hepatic pathologies in the modern world. Some quality parameters of management of patients with liver cirrhosis in the Siberian federal district. Doctor.Ru. 2019; 3(158):6-10. (in Russia).

2. Pimpin L., Cortez-Pinto H., Negro F. et al. Burden of liver disease in Europe: epidemiology and analysis of risk factors to identify prevention policies. Journal of Hepatology. 2018;69:718-735.

3. Nersesov A.V., Zhankalova Z.M., Raisova A.M. et al. Harakteristika ambulatornyh pacientov $s$ zabolevanijami pecheni (hronicheskij virusnyj gepatit, steatoz pecheni, zabolevanija pecheni, voznikshie na fone saharnogo diabeta i ozhirenija), poluchajushhih Jessenciale v kachestve dopolnenija k standartnoj terapii v uslovijah realnoj praktiki (rezultaty mnogocentrovogo issledovanija REPAIR). [Characterization of outpatients suffering from liver conditions (chronic viral hepatitis, hepatic steatosis, hepatic disease related to diabetes or obesity) managed under real life conditions and receiving a treatment with Essentiale as an adjunctive treatment to standard care (the results of multicenter study REPAIR)]. Medicine. 2016;9(171):129-143. (in Russia).

4. Zvyagintseva T.D., Chernobay A.I. Hronicheskie zabolevanija pecheni: fokus na polikompozicionnye rastitelnye gepatoprotektoryantioksidanty. Chronic liver diseases: focus on the polycomponent plant hepatoprotectors-antioxidants. Modern Gastroenterology. 2014;4(78):70-76. (in Russia).

5. Desai N.A., Kotak K.P., Patel S.S. Investigation of epidemiology and etiology of liver diseases and characterization of its association with various factors. Asian Journal of Pharmaceutical and Clinical Research. 2015;8(2):346-349.
6. Oparin A.A., Oparin A.G., Fedchenko Y.G. et al. Ultrazvukovoe yssledovanye pecheny v norme y patologyy. Ultrasound research of the liver in normal and pathology. East European Journal of Internal and Family Medicine. 2016;2:43-54. (in Ukrainian).

7. Ershov V.A., Ryllo A.G. Punkcionnaja gistologicheskaja i citologicheskaja biopsijnaja diagnostika zabolevanij pecheni. Puncture histological and cytological biopsy diagnostics of liver diseases. Grekov's Bulletin of Surgery. 2007;166(1):78-79. (in Russia).

8. Kosarenko E.S., Zuyevskaya T.V., Aksenov V.V. et al. Neinvazivnaja diagnostika zabolevanij pecheni s celju opredelenija stadii zabolevanija (vyrazhennosti fibroza). Noninvasive diagnostics of liver diseases to determine the stage of disease (fibrose expression). Medical Science and Education of the Urals. 2018;4:187-190. (in Russia).

9. ØdegaardS., Nesje L.B., Hausken T.etal.Ultrasonographyin gastroenterology. Scandinavian Journal of Gastroenterology. 2015;26:1-10.

10. Heller M.T., Tublin M.E. The role of ultrasonography in the evaluation of diffuse liver disease. Radiologic Clinics of North America. 2014;52(6):1163-1175.

11. Komarov F.I, Rapoport S.I. Guide to gastroenterology. M .: Medical information agency. 2010: 854. (in Russia).

12. StockK.F., Klein B., Steubl D.etal.Comparison ofapocket-size ultrasound device with a premium ultrasound machine: diagnostic value and time required in bedsideultrasound examination. Abdominal Imaging.2015;40(7):2861-2866.

13. Jepsen P. Comorbidity in cirrhosis. World Journal of Gastroenterology. 2014;20(23):7223-7230.

14. Chepelevska L.A., Dziuba 0.M., Kruchanytsia V.V. Regionalni osoblyvosti smertnosti naselennja Ukrainy vid fibrozu i cyrozu pechinky ta alkogolnoi hvoroby pechinky. Regional features of population mortality caused by liver fibrosis and cirrhosis and alcoholic liver disease. Ukraine. Health of the Nation. 2016;4/1(41):218-224. (in Ukrainian).

\section{ORCID and contributionship:}

Yuliia Ya. Fedulenkova: 0000-0001-8599-9500 A, D, F

Mykhailo S. Myroshnychenko: 0000-0002-6920-8374 A, D, E

Olha M.Astapieva: 0000-0003-1136-6131 ${ }^{B, E}$

Aleksandr A. Fatieiev: 0000-0003-1350-8623 C, F

Kristina Od. Akritova: 0000-0001-5231-523X ${ }^{B, C}$

Dmytro V. Molodan: 0000-0002-7679-828 B,E

\section{Conflict of interest:}

The Authors declare no conflict of interest.

\section{CORRESPONDING AUTHOR Mykhailo S. Myroshnychenko}

Kharkiv National Medical University

27A Svetlaya str., apt. 70, 61129 Kharkiv, Ukraine

tel: $+380501699763,+380961033038$

e-mail:msmyroshnychenko@ukr.net

Received: 17.04 .2020

Accepted: 30.07 .2020

A - Work concept and design, B - Data collection and analysis, C - Responsibility for statistical analysis, D-Writing the article, E-Critical review, $\mathbf{F}$ - Final approval of the article 